\title{
PROBLEMATIKA YURIDIS PERATURAN PEMERINTAH NO. 61 TAHUN 2014 TENTANG KESEHATAN DALAM HUBUNGANNYA DENGAN TERHADAP TINDAKAN ABORSI
}

\author{
Emy Puasa Handayani ${ }^{1}$, Endro Purwandi ${ }^{2}$ \\ 1. Universitas Islam Kadiri, Kediri \\ 2. Polres Kediri
}

\begin{abstract}
ABSTRAK
Aborsi merupakan suatu bentuk kejahatan terhadap nyawa cabang bayi. Adanya pengecualian mengenai legalnya tindakan tersebut, yang berdasarkan Pasal 31, Peraturan Pemerintah Nomor 61 Tahun 2014 tentang kesehatan reproduksi, yaitu apabila diakibatkan kedaruratan medis, dan kehamilan akibat perkosaan. Apakah yang dimaksud dengan aborsi?, dan bagaimanakah tindakan aborsi dapat legal apabila pada dasarnya menyebabkan hilangnya nyawa jabang bayi yang didalam kandungan?.

Melalui pendekatan undang-undang dan konsep hukum ditemukan bahwa, Pasal 31-35, P.P. No 61 Tahun 2014 tentang kesehatan reproduksi, terjadi konflik norma dengan Kitab Undang-undang Hukum Pidana KUHP Pasal 346-349. Tindakan aborsi didalam P.P. No 61 Tahun 2014, Pasal 31-35 terdapat rumusan secara bijak dalam melakukan tindakan medis yaitu dapat mengutamakan keselamatan dari nyawa ibu yang hamil karena terjadi sesuatu didalam rahimnya dan akibat dari kehamilan akibat diperkosa.

Disamping itu bentuk dari aborsi yang dilarang oleh KUHP yaitu Elective abortion adalah menggugurkan yang dilakukan karena alasan lain, hal ini mengarah unsur tindakan pergaulan bebas (Sex bebas) dan lain sebagainya, sehingga menyebabkan kehamilan, dapat dikenakan Pasal 346-349 Kitab Undang-undang Hukum Pidana (KUHP).

Kata Kunci : Aborsi, Kesehatan reproduksi, kriminal, Sex bebas.
\end{abstract}

\section{A. PENDAHULUAN}

Aborsi merupakan bentuk kejahatan terhadap nyawa jabang bayi hal ini dilakukan karena terdapat dua hal yaitu keinginan dari pihak siibu yang mengandung karena permasalahan yang indikasinya daruat medis atau karena memang keinginan dari pihak tertentu akibat menanggung aib karena kehamilan yang tidak diinginkan (kehamilan diluar nikah atau pergaulan bebas). Kehamilan akibat perkosaan ataupun mengalami permasalahan kesehatan komplikasi serius pada saat kehamilan, hal ini menyebabkan suatu tindakan yang diizinkan secara resmi (Legal) didalam dunia medis, dan apabila tidak dilakukan tindakan tersebut akan mengakibatkan kematian ibu yang sedang hamil, ataupun gangguan mental, fisik, dan sosial bagi yang (diakibatkan perkosaan). Hal tersebut telah diatur didalam Pasal 31 Peraturan Pemerintah Nomor 61 Tahun 2014 tentang Kesehatan reproduksi. Namun sejatinya hal ini dilarang oleh negara karena tindakan tersebut merupakan bentuk tindakan kejahatan terhadap nyawa yang termasuk kategori kejahatan menggugurkan kandungan atau menghilangkan nyawa jabang bayi, sebagaimana yang diatur didalam Kitab Undang-Undang Hukum Pidana (KUHP). Dengan Pasal 346-349 Kitab Undang-Undang Hukum Pidana. Adapun hal menjadi suatu bentuk pertanyaan adalah Apakah yang dimaksud dengan aborsi, dan analisa suatu tindakan aborsi dapat legal apabila hal ini akan menghilangkan nyawa jabang bayi yang didalam kandungan. penelitian ini mengetengahkan tema tentang kajian yuridis terhadap Peraturan Pemerintah Nomor 61 Tahun 2014 Tentang Kesehatan Reproduksi.

Banyak alasan seorang wanita melakukan tindakan aborsi, misalnya untuk menutupi aib keluarga dan perasaan malu pada diri sendiri, keluarga serta pandangan buruk dari masyarakat. Anak yang lahir dari hubungan terlarang (incest) tersebut mempunyai kemungkinan jauh dari keadaan normal yang sempurna, namun tidak semuanya. Hal ini karena beberapa generasi dari hasil hubungan incest mengakibatkan kelahiran cacat genetik yang lebih besar.

Apabila terjadi kelahiran, anak perempuan lebih rentan dan berpeluang besar 
terhadap penyakit genetik yang diturunkan orangtuanya. Incest memiliki alasan lebih besar yang patut dipertimbangkan dari kesehatan medis. Banyak penyakit genetik yang berpeluang muncul lebih besar. Sebut saja pada genetik, kromosom yang mengalami gangguan kesehatan jiwa (skizoprenia), Leukodystrophie atau kelainan pada bagian saraf yang disebut milin, ada bagian dari jaringan penunjang pada otak yang mengalami gangguan yang menyebabkan proses pembentukan enzim terganggu.

Selain itu, perkawinan sedarah juga menghasilkan keturunan albino (kelainan pada pigmen kulit) dan keterlambatan mental (idiot) serta perkembangan otak yang lemah. Banyak penyakit keturunan yang akan semakin kuat dilahirkan pada pasangan yang memiliki riwayat genetik buruk dan terjadi incest. Namun, yang harus diwaspadai juga kecacatan kelahiran bisa muncul akibat ketegangan saat ibu mengandung dan adanya rasa penolakan secara emosional dari ibu. 1

Korban perkosaan membutuhkan banyak dukungan, perlindungan dan bantuan. Tetapi dengan melakukan aborsi sama halnya dengan melakukan pemerkosaan yaitu suatu tindakan yang menghancurkan dan mematikan. Tindakan yang menggugurkan janin hasil perkosaan adalah seperti menjawab kekejaman atas seorang wanita yang tidak berdosa (yaitu korban perkosaan) dengan kekejaman atas suatu korban yang tak berdosa juga. Aborsi dapat menyebabkan hilangnya hak satu manusia yang tak berdosa untuk hidup.

Bagi korban perkosaan menjalani kehamilan yang tidak diinginkan adalah suatu hal yang sangat berat. Menjadi korban perkosaan saja sudah berat apalagi ditambah dengan terjadinya kehamilan akibat perkosaan tersebut. Korban akan terus dibayang-bayangi oleh peristiwa perkosaan tersebut yang menyebabkan terjadinya kehamilan yang terus akan menghantuinya dan wanita korban perkosaan tersebut masih harus dihadapkan pada persoalan bagaimana status hukum anak yang dikandungnya apalagi jika yang melakukan perkosaan tersebut masih merupakan saudara sedarah (incest). Tetapi jika wanita tersebut tidak menginginkan kehamilan tersebut dengan

\footnotetext{
${ }^{1}$ http://www.balipost.co.id/balipostcetak/2006 $/ 11 / 22 /$ kes1.htm).
}

jalan menggugurkan kandungannya hal ini sama dengan dia membunuh bakal calon anak kandungnya sendiri.

Aborsi dengan alasan perkosaan, terutama perkosaan, masih menjadi perdebatan oleh banyak kalangan. Kitab Undang-Undang Hukum Pidana (KUHP) sebagai dasar hukum pidana di Indonesia sama sekali melarang tindakan aborsi, tetapi PP No. 61 Tahun 2014 tentang Kesehatan masih memberi ruang terjadinya aborsi dengan alasan tertentu, yaitu dengan alasan adanya indikasi medis. Indikasi medis di dalam undang-undang hanya menyebutkan secara limitatif, apakah perkosaan dapat dijadikan indikasi medis untuk melakukan aborsi sehinggga meniadakan pidana dari perbuatan aborsi tersebut.

Berdasarkan penjelasan di atas, maka Penulis tertarik untukmenuliskannya dalam bentuk tesis dengan judul : "Problematika Yuridis Peraturan Pemerintah No. 61 Tahun 2014 Tentang Kesehatan Dalam Hubunganya Dengan Terhadap

Tindakan Aborsi".

Rumusan Masalah

Berdasarkan latar belakang di atas, maka rumusan masalah dalam proposal penelitian ini yaitu:

1. Apa maksud dan tujuan Peraturan Pemerintah No.61 Tahun 2014 Tentang Kesehatan ?

2. Bagaimana ketentuan pidana aborsi menurut KUHP dalam hubunganya dengan Peraturan Pemerintah No.61 Tahun 2014 Tentang Kesehatan?

\section{Tujuan Penelitian}

Berdasarkan rumusan masalah di atas maka tujuan dari penelitian ini adalah sebagai berikut :

1. Untuk mengetahui maksud dan tujuan Peraturan Pemerintah No.61 Tahun 2014 Tentang Kesehatan.

2. Untuk mengetahui ketentuan pidana aborsi menurut KUHP dalam hubunganya dengan Peraturan Pemerintah No.61 Tahun 2014 Tentang Kesehatan.

\section{Kegunaan Penelitian}

Adapun manfaat yang diharapkan dari penelitian ini yaitu :

1. Secara teoritis Diharapkan hasil penelitian ini dapat dijadikan bahan referensi bagi penerapan hukum pada khususnya maupun bagi masyarakat pada umumnya. 
2. Secara praktis Diharapkan dari penelitian ini, dapat memperkaya referensi dan literatur dalam dunia kepustakaan tentang tindakan aborsi.

\section{Metode Penelitian}

Metode penelitian merupakan faktor penting dalam penelitian, hal ini disebabkan karena disamping digunakan untuk mendapat data yang sesuai dengan tujuan penelitian, metode penelitian juga digunakan agar mempermudah pengembangan data guna kelancaran penyusunan penulisan Hukum.

Metode penelitian adalah suatu cara yang akan digunakan untuk mendapatkan suatu data dari objek penelitian, yang kemudian data tersebut akan diolah guna mendapatkan data yang lengkap dan hasil penelitian yang dapat dipertanggungjawabkan secara ilmiah, adapun yang menyangkut tentang metodologi penelitian dalam penelitian ini meliputi :

\section{Jenis Penelitian}

Penelitian ini adalah penelitian yang besifat normatif atau jenis penelitian doktrinal, yaitu penelitian yang didasarkan pada penelitian kepustakaan (library research), Penelitian kepustakaan (library research) adalah penelitian yang dilakukan dengan mengumpulkan data dari bahan kepustakaan yang berhubungan dengan permasalahan yang diteliti. Dalam hal ini penulis berusaha menjelaskan aspek hukum dan menggambarkan data secara tepat tentang tindakan.

\section{Jenis dan Sumber Data}

Jenis dan Sumber Data yang digunakan dalam penelitian ini yaitu :

Sumber data primer yaitu data yang diperoleh langsung dari sumber utama. Adapun sumber data primer yang dibutuhkan dalam penulisan tesis ini adalah : "KUHP dan Peraturan Pemerintah No.61 Tahun 2014 Tentang Kesehatan.

Sumber data sekunder, telah berbentuk dan diisi oleh penelitian-penelitian terdahulu, sehingga penelitian kemudian, tidak mempunyai pengawasan terhadap pengumpulan, pengelolaan penunjang maupun analisa konstruksi data, tidak terbatas oleh ruang dan waktu. berupa buku-buku, jurnal-jurnal ilmiah, naskah-naskah, serta literatur lainnya yang dapat menunjang upaya penulis dalam memecahkan masalah yang penulis angkat ini. Adapun bukubuku yang penulis butuhkan adalah buku-buku tentang Aborsi, Teknik Pengumpulan data, dalam hal ini penulis akan melakukan identifikasi wacana dari buku-buku, majalah atau artikel, jurnal, web (internet), ataupun informasi yang berhubungan dengan judul penulisan, melalui studi kepustakaan mengumpulkan, membaca, menelaah, mencatat data-data yang berkaitan dengan penelitian penulis dari sumber data primer dan data sekunder kemudian pengelolaan data sesuai dengan teknis analisis Analisis terhadap data penulis peroleh adalah dengan menggunakan analisis deskriptif.

\section{Analisis Data}

Data yang diperoleh dari data sekunder akan diolah dan dianalisis berdasarkan rumusan masalah yang telah diterapkan sehingga diharapkan dapat diperoleh gambaran yang jelas. Analisis data yang digunakan adalah analisis data yang berupaya memberikan gambaran secara jelas dan konkrit terhadap objek yang dibahas secara kualitatif dan selanjutnya data tersebut disajikan secara dekriptif yaitu menjelaskan, menguraikan dan menggambarkan sesuai dengan permasalahan yang erat kaitannya dengan penelitian ini.

\section{B. PEMBAHASAN}

\section{Apa maksud tujuan Peraturan Pemerintah No.61 Tahun 2014 Tentang Kesehatan ?}

Seiring perkembangan zaman dan ilmu pengetahuan serta teknologi, sebagaimana era saat ini, masalah aborsi tetap menjadi masalah krusial bahkan menjadi fenomena politik dalam sejarah manusia modern. Status hukum aborsi pada era ini diperjelas dengan argumentasi yang konstruktif. Hampir setengah dari kehamilan yang tidak diharapkan berakhir dengan aborsi. Sementara itu, kendati dilarang, baik oleh Kitab Undang-Undang Hukum Pidana (KUHP), Undang-Undang (UU), maupun fatwa Majelis Ulama Indonesia (MUI) atau majelis tarjih Muhammadiyah, praktik aborsi (pengguguran kandungan) di Indonesia tetap tinggi dan mencapai 2,5 juta kasus setiap tahunnya dan sebagian besar dilakukan oleh para remaja. ${ }^{2}$

Aborsi adalah pengeluaran hasil konsepsi secara prematur dari uterus-embrio,

\footnotetext{
${ }^{2}$ http://rahmatikhsanmubut.blogspot.com/2014 /06/makalah-bahaya-aborsi.html (diakses pada tanggal 9 Desember 2014 pukul 15:00 WIB)
} 
atau fetus yang belum dapat hidup. ${ }^{3}$ Aborsi dilarang jika pelaksanaannya terjadi sesudah janin terbentuk atau sudah mendapatkan nyawa, yakni sejak ada tanda- tanda pergerakan janin (quickening).4 Istilah aborsi atau abortus secara kebahasaan berarti keguguran kandungan, pengguguran kandungan, atau membuang janin. Dalam terminologi kedokteran berarti terhentinya kehamilan sebelum 28 minggu. Dalam istilah hukum, berarti pengeluaran hasil konsepsi dari rahim sebelum waktunya (sebelum dapat lahir secara alamiah). 5

Aborsi pada umumnya dianggap oleh sebagian besar masyarakat sebagai tindak pidana. Namun, dalam hukum positif Indonesia, tindakan aborsi pada sejumlah kasus tertentu dapat dibenarkan apabila merupakan abortus provokatus medicialis. Sedangkan aborsi yang digerenalisasi menjadi suatu tindak pidana disebut abortus provokatus criminalis.

Perkembangan berikutnya masalah aborsi ini menjadi kontroversi sejak diberlakukannya Peraturan Pemerintah Nomor 61 Tahun 2014 tentang Kesehatan Reproduksi pada tanggal 21 Juli 2014. Beberapa pasal yang menjadi polemik adalah Pasal 31 dan Pasal 34, yang menyatakan adanya legalisasi terhadap tindakan aborsi

Pasal 31 Peraturan Pemerintah Nomor 61 Tahun 2014:

(1) Tindakan aborsi hanya dapat dilakukan berdasarkan:

a. indikasi kedaruratan medis; atau b.

kehamilan akibat perkosaan.

(2) Tindakan aborsi akibat perkosaan

sebagaimana dimaksud pada Ayat (1)

huruf b hanya dapat dilakukan apabila usia

kehamilan paling lama berusia

40 (empat puluh) hari dihitung sejak hari pertama haid terakhir.

Pasal 34 Peraturan Pemerintah Nomor 61 Tahun 2014:

(1) Kehamilan akibat perkosaan sebagaimana

${ }^{3}$ Dorland, Kamus Kedokteran Edisi 29, Jakarta : EGC, 2002)

${ }^{4}$ CB. Kusmaryanto, scj., Kontroversi Aborsi, cet. II (Jakarta: Grasindo, 2004), hlm. 27.

5 Abdul Aziz Dahlan, Ensiklopedi Hukum Islam, cet. I (Jakarta: PT. Ikhtisar Baru Van Hoev, 1996), hlm. 7. dimaksud dalam Pasal 31 Ayat (1) huruf b merupakan kehamilan hasil hubungan seksual tanpa adanya persetujuan dari pihak perempuan sesuai dengan ketentuan peraturan perundang-undangan.

(2) Kehamilan akibat perkosaan sebagaimana dimaksud pada Ayat (1)dibuktikan dengan:

a. usia kehamilan sesuai dengan kejadian perkosaan, yang dinyatakan oleh surat keterangan dokter; dan

b. keterangan penyidik, psikolog, dan/atau ahli lain mengenai adanya dugaan perkosaan.

Kemunculan Peraturan Pemerintah No. 61 Tahun 2014 menimbulkan sutau dekriminalisasi terhadap aborsi dengan 2 (dua) syarat yang terdapat di dalam Pasal 31 dan Pasal 34 peraturan tersebut. Dekriminalisasi yaitu penggolongan suatu perbuatan yg pada mulanya dianggap sebagai peristiwa pidana, tetapi kemudian dianggap sebagai perilaku biasa. Peraturan ini juga beresiko melahirkan pihak yang memanfaatkan legalisasi terbatas untuk mengaborsi anak korban perzinahan. Hal itulah yang menjadi poin utama untuk dicegah guna menghindari pasangan muda yang tak sah melakukan aborsi.

Peraturan pemerintah tersebut dinilai memberi peluang kepada pasangan yang melakukan hubungan tidak sah untuk tidak punya anak dan hal ini dapat berdampak pada meningkatnya perilaku perzinahan.

Pihak yang tidak setuju menyatakan bahwa aborsi yang dimaksud dalam ketentuan Peraturan Pemerintah Nomor 61 Tahun 2014 melanggar Pasal 338 KUHP dan bertentangan dengan aspek sosiologis masyarakat. Pasal 299, Pasal 338, Pasal 346, Pasal 348 dan Pasal 349 KUHP adalah pasal yang melarang aborsi dengan sanksi hukum berat. Peraturan Pemerintah ini memang mendapatkan dukungan dari beberapa lembaga keagamaan. Beberapa argumentasi ini barangkali bisa dijadikan referensi terhadap dukungan itu. Dalam agama Islam, misalnya didasarkan pada argumentasi bahwa baru pada usia 4 bulan roh seseorang dihembuskan. Dalam agama Buddha, masih diizinkan adanya aborsi karena bagi mereka kesadaran menjadi kunci keutuhan manusia. Itu berarti sejak syaraf otak terbentuk baru hak hidupnya tidak bisa diganggu gugat. Dalam beberapa argumentasi lain, bahkan dengan 
prinsip otonomi, kehidupan individu bahkan diakui baru sesudah dilahirkan.

Lepas dari alasan-alasan teologis dan juga filosofis tersebut, para embriolog modern biasanya mengakui bahwa hidup dimulai sejak selesainya proses pembuahan. Dengan energi yang berasal dari dalam dirinya sendiri, embrio terus berkembang, meskipun pasokan sumber energi berasal dari induknya. Hal ini kemudian mendorong tokoh-tokoh dari 6 lembaga agama di Indonesia menandatangani pernyataan bahwa hak hidup seseorang mesti dijamin sejak selesainya pembuahan.

Mengorbankan anak dalam rangka menghindari rasa trauma juga tidak bisa dibenarkan secara moral. Bagaimanapun, yang pantas mendapatkan hukuman di sini adalah pihak pemerkosanya, bukan anaknya. Maka yang perlu diatur tentu saja adalah bagaimana hukuman terhadap pelaku perkosaan. Untuk memperjuangkan hak hidup sang ibu, janin yang ada dalam kandungannya terpaksa dikorbankan. Meskipun bisa ditolerir, alasan ini sebenarnya mengandung kelemahan karena janin dalam keadaan tanpa pembelaan sama sekali.

Apabila diibaratkan, ketika seorang militer yang punya senjata kemudian melawan anak kecil sipil, jelas tidak bisa dibenarkan secara moral kalau sampai membunuh. Tetapi, karena hal ini mengindikasikan dengan nyawa sang ibu terancam, tindakan itu masih bisa dipertanggungjawabkan secara moral sedangkan dalam kasus perkosaan, intensinya ada dua, menghindarkan korban dari rasa malu dan menghindarkan korban dari rasa trauma. Jika tujuan langsungnya hanya sekedar menghindari rasa malu, jelas alasan ini sangat lemah untuk diterima secara moral.

Tujuan Penyelenggaraan Aborsi Peratuan Pemerintah No. 61 Tahun 2014, tentang Kesehatan Reproduksi, merupakan tujuan pemerintah untuk menjamin kesehatan organ reproduksi yang sehat. Aborsi merupakan salah satu bagian tindakan medis yang mengarah mengenai tujuan dari kesehatan reproduksi. Hal ini telah diatur tata cara penyelenggaraan aborsi, yang tertuang didalam Pasal 35, Peraturan Pemerintah No 61 Tahun 2014 tentang Kesehatan reproduksi, tindakan aborsi hanya dapat dilakukan apabila terjadi kedaruratan medis seperti halnya letak jabang bayi yang tidak di rahim sehingga mengakibatkan pendarahan, dan kehamilan akibat perkosaan, tindakan aborsi ini bukan karena motifnya melakukan sex diluar dari pernikahan sehingga ingin menutupi aib akibat kecerobohannya ingin menghilangkan jejak akibat dari perbuatanya.

Bagaimana ketentuan pidana aborsi menurut KUHP dalam hubunganya dengan Peraturan Pemerintah No.61 Tahun 2014 Tentang Kesehatan ?

\section{Pengertian aborsi menurut KUHP.}

Berdasar penelitian yang penulis lakukan, tindak pidana aborsi di dalam Kitab Undang-Undang Hukum Pidana (KUHP) diatur pada Pasal 299, Pasal 346- 349. Ketentuan mengenai aborsi dapat dilihat dalam Bab XIV Buku Kedua KUHP tentang kejahatan terhadap nyawa (khususnya Pasal 346-349). Adapun rumusan selengkapnya pasalpasal tersebut:

Pasal 299 (1) Barangsiapa dengan sengaja mengobati seorang wanita atau menyuruhnya supaya diobati dengan sengaja memberitahukan atau ditimbulkan harapan, bahwa karena pengobatan itu hamilnya dapat digugurkan, diancam pidana penjara paling lama empat tahun atau denda paling banyak tiga ribu rupiah (2) Jika yang bersalah berbuat demikian untuk mencari keuntungan atau menjadikan perbuatan tersebut sebagai pencarian atau kebiasaan atau jika ia seorang tabib, bidan, atau juru obat, pidananya tersebut ditambah sepertiga (3) Jika yang bersalah, melakukan kejahatan tersebut dalam menjalankan pencarian, maka dapat dicabut haknya untuk melakukan pencarian (Soesilo, 1995:218)

Pasal 346 Seorang wanita yang sengaja menggugurkan atau mematikan kandungannya atau menyuruh orang lain untuk itu, diancam dengan pidana penjara paling lama empat tahun

Pasal 347 (1) Barang siapa dengan sengaja menggugurkan atau mematikan kandungan seorang wanita tanpa persetujuannya, diancam dengan pidana penjara paling lama dua belas tahun (2) Jika perbuatan itu mengakibatkan matinya wanita tersebut, dikenakan pidana penjara paling lama lima belas tahun.

Pasal 348 (1) Barang siapa dengan sengaja menggugurkan atau mematikan kandungan seorang wanita dengan persetujuannya, diancam dengan pidana penjara paling lama lima tahun enam bulan (2) Jika perbuatan itu mengakibatkan matinya 
wanita tersebut, dikenakan pidana penjara paling lama tujuh tahun

Pasal 349 Jika seorang tabib, bidan atau juru obat membantu melakukan kejahatan yang tersebut Pasal 346, ataupun melakukan atau membantu melakukan salah satu kejahatan yang diterangkan pasal 347 dan 348, maka pidana yang ditentukan dalam pasal itu dapat ditambah dengan sepertiga dapat dicabut hak untuk menjalankan pencarian dalam mana kejahatan dilakukan (Soesilo,1995:243-244)

Penjelasan terhadap pasal-pasal tersebut sebagai berikut :

a. Pengguguran anak dari kandungan hanyalah dapat dihukum, jika anak yang berada dalam kandungan itu selama dilakukan usaha pengguguran berada dalam keadaan hidup. Undang-undang tidak mengenal anggapan hukum yang dapat memberi kesimpulan bahwa anak yang berada di dalam kandungan itu berada dalam keadaan hidup ataupun mempunyai kemungkinan tetap hidup. ${ }^{6}$

b. Untuk pengguguran yang dapat dihukum, disyaratkan bahwa anak yang berada dalam kandungan itu selama dilakukan usaha pengguguran kandungan berada dalam keadaan hidup. Tidak perlu bahwa anak itu menjadi mati karena usaha pengguguran tersebut. Kenyataan bahwa anak itu dilahirkan dalam keadaan selamat, tidaklah menghapus bahwa kejahatan itu selesai dilakukan. Undang-undang tidak membedakan antara berkurang atau lebih lancarnya pertumbuhan anak yang hidup didalam kandungan melainkan menetapkan pemisahan dari tubuh si ibu yang tidak pada waktunya sebagai perbuatan yang dapat dihukum. ${ }^{7}$

c. Disyaratkan bahwa anak yang berada di dalam kandungan itu hidup dan si pelaku mempunyai kesengajaan untuk menggugurkan anak yang berada di dalam keadaan hidup itu. Dianggap bahwa kesengajaan itu ada, apabila selama proses kelahiran anak itu berada dalam keadaan hidup dan si pelaku diliputi oleh anggapan bahwa demikianlah halnya (H.R. 29 Juli 1907. W. 8580).

d. Alat-alat pembuktian yang disebutkan oleh hakim didalam putusannya haruslah dapat ditarik suatu kesimpulan, bahwa wanita itu hamil dan mengandung anak yang hidup dan

${ }^{6}$ (H.R. 1 Nopember 1897. W.7038).

7 (H.R. 12 April 1898. W. 7113). bahwa tertuduh mempunyai maksud untuk dengan sengaja menyebabkan gugur atau meninggalnya anak tersebut. ${ }^{8}$ Secara singkat, dari uraian diatas dapat dijelaskan bahwa yang dapat dihukum, menurut KUHP dalam kasus aborsi ini adalah:

a. Pelaksanaan aborsi, yaitu tenaga medis atau dukun atau orang lain dengan hukuman maksimal 4 tahun ditambah sepertiga dan bisa juga dicabut hak untuk berperaktik b. Wanita yang menggugurkan kandungannya, dengan hukuman maksimal 4 tahun

c. Orang- orang yang terlibat secara langsung dan menjadi penyebab terjadinya aborsi itu dihukum dengan hukuman bervariasi (Kusmaryanto, 2002:40).

Oleh karena itu maka perbuatan mematikan kandungan baru dapat dinyatakan telah selesai atau terwujud setelah dari perbuatan itu menimbulkan (1) kelahiran dan (2) kematian dari bayi atau janin tersebut. Sedangkan perbuatan menggugurkan baru dapat dinyatakan terwujud atau selesai dilakukan, setelah perbuatan itu menimbulkan akibat bayi atau janin keluar/lahir dari rahim, kelahiran yang mana merupakan kelahiran yang belum waktunya menurut alam, yang dapat berupa bayi atau janin dalam keadaan hidup atau sudah mati. ${ }^{9}$

Unsur yang ketiga dan keempat yang terdapat dalam Pasal 346 KUHP yaitu menyuruh orang lain menggugurkan kandungan, dan yang terakhir menyuruh orang lain untuk mematikan kandungan, dalam melakukan perbuatan ini menyangkut dua orang yang berperan untuk menimbulkan akibat bayi atau janin keluar sebelum waktunya dan/atau matinya bayi atau janin yang dilahirkan sebelum waktunya. $\mathrm{Di}$ sini yang dimaksud dengan menyangkut dua orang adalah di mana perbutan menggugurkan dan/atau mematikan janin atau bayi dilakukan oleh 2 orang atau lebih. Yang pertama yaitu perempuan yang mengandung, dimana perempuan dalam hal ini adalah pihak yang menyuruh melakukan perbuatan mengugurkan dan/atau mematikan bayi atau janin dan pihak yang disuruh melakukan perbuatan tersebut.

Jika dibaca secara seksama maka

8 (H.R. 20 Desember 1943, 1994 No. 232)

(Soenarto, 1994:211).

${ }^{9}$ (Adami Chazawi, 2001:115-116) 
terdapat keterkaitan antara Pasal 346, 347, dan 348 KUHP. Antara Pasal 346 dan 347 sendiri terdapat persamaan dan perbedaan masing-masing pasal. Persamaannya adalah di dalam pasal tersebut sama-sama mengatur mengenai perbuatan menggugurkan atau mematikan dengan obyek yang sama yaitu kandungan seorang perempuan. Perbedaannya adalah pada Pasal 346 KUHP pengguguran tersebut dilakukan dengan sengaja baik oleh perempuan itu sendiri atau dengan cara menyuruh orang lain sedangkan pada Pasal 347 KUHP perbuatan menggugurkan atau mematikan tersebut tidak mendapat ijin dari perempuan yang sedang mengandung atau dengan kata lain tanpa persetujuan. Namun jika perbuatan menggugurkan atau mematikan kandungan tersebut mendapat persetujuan dari perempuan yang mengandung maka dapat dijerat dengan Pasal 348 KUHP. Pasal 347 ayat (1) KUHP terdapat beberapa bagian inti delik (delicts bestanddelen) yaitu:

1. Sengaja

2. Menggugurkan kandungan seseorang

3. Tanpa persetujuan

Melihat perkembangan zaman khususnya bidang kesehatan. Penulis berpendapat, bahwa rumusan Pasal 349 harus diartikan juga berlaku untuk dokter ataupun paramedis yang melakukan pembantuan untuk terjadinya kejahatan tersebut, tidak terbatas pada bidan serta juru obat.

Selain ancaman pidana penjara, Pasal 349 juga menyebutkan adanya pidana tambahan bagi tabib, bidan ataupun juru obat yang melakukan pembantuan terjadinya tindak pidana aborsi. Rumusan Pasal 349 tersebut menyebutkan bahwa pidana tambahan yang dapat dijatuhkan adalah pencabutan hak untuk menjalankan pencaharian dalam mana kejahatan tersebut dilakukan. Artinya adalah hakim melalui putusannya dapat mencabut hak/izin praktek dari terpidana yang berkaitan dengan tindak pidana aborsi, sebagai contoh pencabutan izin sebagai bidan.

$$
\text { Mengenai sampai kapankah }
$$

pencabutan hak untuk melakukan pencaharian sebagaimana dimaksud dalam Pasal 349 tersebut berlaku tersebut hendaknya kita melihat Pasal 38 KUHP. Pasal tersebut menyatakan bahwa pencabutan hak dilakukan jika selama seumur hidup dalam hal pidana mati atau penjara seumur hidup. Rumusan selanjutnya menyebutkan bahwa jika pidana yang dijatuhkan berupa pidana penjara atau kurungan dalam waktu tertentu, maka lamanya pencabutan hak paling sedikit adalah dua tahun dan paling banyak lima tahun dari pidana pokoknya dan dalam hal pidana pokoknya berupa denda maka pencabutan hak paling sedikit dua tahun dan paling banyak lima tahun. Akan tetapi, pada akhirnya hakim yang akan memutuskan mengenai lamanya pencabutan hak tersebut dengan memperhatikan berbagai pertimbangan.

Uraian dari rumusan pasal-pasal di dalam KUHP diatas menunjukkan bahwa menurut KUHP, aborsi dilarang dengan alasan apapun dan dilakukan oleh siapapun, baik itu pelaku atau pun pembantu. KUHP sama sekali tidak memberikan celah bagi terjadinya aborsi, yang sanksi hukuman bagi yang melanggar jika disimpulkan adalah sebagai berikut :

a. empat tahun bagi wanita yang dengan sengaja mematikan janinnya (Pasal 346 KUHP),

b. dua belas tahun bagi seseorang yang menggugurkan kandungan wanita tanpa persetujuan (Pasal 347 ayat (1) KUHP),

c. Maksimal 15 (lima belas tahun) bagi pengguguran kandungan tanpa persetujuan wanita yang berakibat matinya wanita tersebut, dan juga yang dengan persetujuan (Pasal 347 ayat (2) KUHP),

d. lima tahun 6 (enam bulan) bagi pengguguran yang disengaja dengan kesepakatan wanita (Pasal 348 ayat (1)

e. tujuh tahun pengguguran disengaja dengan kesepakatan yang berakibat mati (Pasal 348 ayat (2)).

f. Ditambah 1/3 (sepertiga) lebih tinggi bagi ahli medis dibanding selain ahli medis. Bahkan ditambah dengan pencabutan izin praktek yang digunakan untuk melakukan perbuatan pidana (Pasal 349 KUHP).

Rumusan pasal-pasal di dalam KUHP jika diperhatikan dengan seksama sama sekali tidak memberikan toleransi terhadap terjadinya aborsi dengan alasan dan latar belakang apapun serta dilakukan oleh siapapun. Sebelum adanya undangundang Kesehatan, ketentuan ini terasa memberatkan terutama bagi tim medis yang melaksanakan aborsi dengan alasan medis.

\section{Pengertian Peraturan Pemerintah No.61 Tahun 2014 Tentang Kesehatan.}

Kemunculan Peraturan Pemerintah 
No. 61 Tahun 2014 menimbulkan sutau dekriminalisasi terhadap aborsi dengan 2 (dua) syarat yang terdapat di dalam Pasal 31 dan Pasal 34 peraturan tersebut. Dekriminalisasi yaitu penggolongan suatu perbuatan yg pada mulanya dianggap sebagai peristiwa pidana, tetapi kemudian dianggap sebagai perilaku biasa. Peraturan ini juga beresiko melahirkan pihak yang memanfaatkan legalisasi terbatas untuk mengaborsi anak korban perzinahan. Hal itulah yang menjadi poin utama untuk dicegah guna menghindari pasangan muda yang tak sah melakukan aborsi. Peraturan pemerintah tersebut dinilai memberi peluang kepada pasangan yang melakukan hubungan tidak sah untuk tidak punya anak dan hal ini dapat berdampak pada meningkatnya perilaku perzinahan.

Pihak yang tidak setuju menyatakan bahwa aborsi yang dimaksud dalam ketentuan Peraturan Pemerintah Nomor 61 Tahun 2014 melanggar Pasal 338 KUHP dan bertentangan dengan aspek sosiologis masyarakat. Pasal 299, Pasal 338, Pasal 346, Pasal 348 dan Pasal 349 KUHP adalah pasal yang melarang aborsi dengan sanksi hukum berat. Peraturan Pemerintah ini memang mendapatkan dukungan dari beberapa lembaga keagamaan. Beberapa argumentasi ini barangkali bisa dijadikan referensi terhadap dukungan itu. Dalam agama Islam, misalnya didasarkan pada argumentasi bahwa baru pada usia 4 bulan roh seseorang dihembuskan. Dalam agama Buddha, masih diizinkan adanya aborsi karena bagi mereka kesadaran menjadi kunci keutuhan manusia. Itu berarti sejak syaraf otak terbentuk baru hak hidupnya tidak bisa diganggu gugat. Dalam beberapa argumentasi lain, bahkan dengan prinsip otonomi, kehidupan individu bahkan diakui baru sesudah dilahirkan. ${ }^{10}$

Mengorbankan anak dalam rangka menghindari rasa trauma juga tidak bisa dibenarkan secara moral. Bagaimanapun, yang pantas mendapatkan hukuman di sini adalah pihak pemerkosanya, bukan anaknya. Maka yang perlu diatur tentu saja adalah bagaimana hukuman terhadap pelaku perkosaan. Untuk

${ }^{10}$ http://m.kompasiana.com/post/read/668500/3/leg alisasi-aborsi-karena-perkosaan-salah-alamat- yangsalah-bapaknya.html (diakses pada tanggal 9 Desember 2014 pukul 15:30 WIB) memperjuangkan hak hidup sang ibu, janin yang ada dalam kandungannya terpaksa dikorbankan. Meskipun bisa ditolerir, alasan ini sebenarnya mengandung kelemahan karena janin dalam keadaan tanpa pembelaan sama sekali. Apabila diibaratkan, ketika seorang militer yang punya senjata kemudian melawan anak kecil sipil, jelas tidak bisa dibenarkan secara moral kalau sampai membunuh. Tetapi, karena hal ini mengindikasikan dengan nyawa sang ibu terancam, tindakan itu masih bisa dipertanggungjawabkan secara moral sedangkan dalam kasus perkosaan, intensinya ada dua, menghindarkan korban dari rasa malu dan menghindarkan korban dari rasa trauma. Jika tujuan langsungnya hanya sekedar menghindari rasa malu, jelas alasan ini sangat lemah untuk diterima

Harus diakui aborsi dilakukan dengan bermacam-macam alasan, salah satunya akibat perkosaan. Banyak yang beranggapan bahwa anak yang dikandung oleh korban perkosaan pada dasarnya tidak diharapkan oleh wanita korban perkosaan, pada saat terjadi perkosaan ia tidak memiliki pilihan atau pun kemampuan untuk mengelak hingga akhirnya terjadi kehamilan pada dirinya. Tidak jarang dalam kasus perkosaan tersebut dilakukan oleh orangorang yang memiliki hubungan kekerabatan ataupun hubungan darah dengan korban, yang dikenal dengan incest. Anak hasil perkosaan inilah yang dianggap sebagai anak yang tidak diharapkan, karena dianggap dapat menjadi beban tidak saja bagi ibu, tetapi dapat juga menjadi beban bagi keluarga.

Salah satu jalan keluar yang dilakukan oleh mereka agar tidak terlahir anak yang tidak diinginkan adalah dengan melakukan pengguguran kandungan. Sampai saat ini masih menjadi pro kontra mengenai apakah aborsi yang dilakukan oleh korban perkosaan dapat dibenarkan. Kaum yang kontra menyatakan bahwa dengan alasan apapun aborsi dilarang, termasuk bagi korban perkosaan.

Kaum ini menyatakan bahwa anak merupakan anugerah Tuhan yang mempunyai hak untuk hidup. Mereka berpandangan bahwa janin mempunyai hak hidup yang tidak boleh dirampas oleh siapapun, termasuk oleh ibu yang mengandungnya. Melakukan aborsi sama saja dengan melakukan pembunuhan, dan pembunuhan merupakan dosa yang sangat besar.

Kemunculan Peraturan Pemerintah 
No. 61 Tahun 2014 menimbulkan sutau dekriminalisasi terhadap aborsi dengan 2 (dua) syarat yang terdapat di dalam Pasal 31 dan Pasal 34 peraturan tersebut. Dekriminalisasi yaitu penggolongan suatu perbuatan yg pada mulanya dianggap sebagai peristiwa pidana, tetapi kemudian dianggap sebagai perilaku biasa. Peraturan ini juga beresiko melahirkan pihak yang memanfaatkan legalisasi terbatas untuk mengaborsi anak korban perzinahan. Hal itulah yang menjadi poin utama untuk dicegah guna menghindari pasangan muda yang tak sah melakukan aborsi. Peraturan pemerintah tersebut dinilai memberi peluang kepada pasangan yang melakukan hubungan tidak sah untuk tidak punya anak dan hal ini dapat berdampak pada meningkatnya perilaku perzinahan.

\section{KESIMPULAN}

Setelah menguraikan hasil penelitian pada bab sebelumnya, maka akhirnya dapat ditarik kesimpulan sebagai berikut:

1. Pengaturan aborsi di dalam KUHP diatur di dalam Pasal 299, 346 -349. Di dalam rumusan KUHP tidak memberikan ruang sama sekali terhadap pelaksanaan aborsi. Pasal 346 ditujukan bagi orang yang menggugurkan kandungannya atau membiarkan orang lain untuk itu.

2. Pasal 347 dan Pasal 348 mempunyai konstruksi yang hampir sama, perbedaannya hanya terletak pada perbuatan tersebut dilakukan tanpa persetujuan dari wanita hamil (Pasal 347) dan dilakukan dengan persetujuan dari wanita hamil (Pasal 348). Masing-masing mengenal adanya keadaan memperberat pidana yang tercantum di dalam ayat (2) nya, yaitu jika perempuan itu mati. Pasal 349 ditujukan kepada tabib, bidan atau juru obat yang melakukan pembantuan terjadinya aborsi. Jika dilihat seksama rumusan

3. Pasal 349 tidak memuat rumusan delik tersendiri, rumusannya tetap sama dengan Pasal 346 dalam hal pembantuan terjadinya tindak pidana aborsi. Begitu pula jika tabib, bidan dan juru obat tersebut melakukan atau membantu melakukan delik dalam Pasal 347 (tanpa persetujuan yang hamil) dan Pasal 348 (dengan persetujuan yang hamil) pidana nya dapat ditambah dengan sepertiga.
KUHP hanya mengenal sanksi penjara bagi pelanggar aturan tersebut.

4. Kemunculan Peraturan Pemerintah No. 61 Tahun 2014 memberikan ruang terjadinya aborsi dengan alasan tertentu terhadap aborsi dengan 2 (dua) syarat yang terdapat di dalam Pasal 31 dan Pasal 34 peraturan tersebut. Peraturan ini juga beresiko melahirkan pihak yang memanfaatkan legalisasi terbatas untuk mengaborsi anak korban perzinahan. Hal itulah yang menjadi poin utama untuk dicegah guna menghindari pasangan muda yang tak sah melakukan aborsi. Peraturan pemerintah tersebut dinilai memberi peluang kepada pasangan yang melakukan hubungan tidak sah untuk tidak punya anak dan hal ini dapat berdampak pada meningkatnya perilaku perzinahan.

\section{DAFTAR PUSTAKA \\ BUKU}

Teguh Prasetyo, 2011, Hukum Pidana, Jakarta: Raja Grafindo.

Chazawi, Adami, 2002. Pelajaran Hukum Pidana I, Jakarta: Raja Grafindo Persada.

Soesilo, R. 1986. Kitab Undang-undang Hukum Pidana Serta Komentarkomentarnya Lengkap Pasal demi Pasal, Bogor: Politea.

Sudarto. 1990. Hukum Pidana I. Semarang: Yayasan Sudarto.

P.A.F. Lamintang. 1990. Hukum Pidana Indonesia. Bandung: Sinar Baru. 1996. Dasar-Dasar Hukum Pidana Indonesia. Bandung :Citra Aditya Bakti.

JS. Badudu dan Sutan Mohammad Zain. 1996. Kamus umum Bahasa Indonesia. Jakarta: Pustaka Sinar Harapan.

Lilien Eka Chandra. 2006. Tanpa Indikasi Medis Ibu, Aborsi sama dengan Kriminal. Lifestyle.

Kusmaryanto, C. B. 2002, Kontroversi Aborsi, Gramedia Widiasarana Indonesia : Jakarta.

Dewi sulistianingsih. 2007. "Abortus Provocatus bagi Korban Perkosaan". Jurnal Hukum Pandecta Fakultas Ilmu Hukum Universitas Negeri Semarang. Vol. 1 No. 1. 
Website

Aborsi.

http://Id.Wikipedia.Org/Wiki/Gugur_

Kandungan.

Agung dan Hoge Raad. Jakarta: PT Raja Grafindo Persada.

http://rahmatikhsanmubut.blogspot.com/2014

/06/makalah-bahaya-aborsi.html

(diakses pada tanggal 9 Desember 2014 pukul 15:00 WIB)

Dorland, Kamus Kedokteran Edisi 29, (Jakarta : EGC, 2002)

CB. Kusmaryanto, scj., Kontroversi Aborsi, cet. II (Jakarta: Grasindo, 2004), hlm. 27.

Abdul Aziz Dahlan, Ensiklopedi Hukum Islam, cet. I (Jakarta: PT. Ikhtisar Baru Van Hoev,1996), hlm. 7.

H.R. 1 Nopember 1897. W.7038

(H.R. 12 April 1898. W. 7113).

(H.R. 20 Desember 1943, 1994 No. 232) (Soenarto, 1994:211).

Adami Chazawi, 2001:115-116)

Adami Chazawi, 2001:118).

http://m.kompasiana.com/post/read/668500/

3/legalisasi-aborsi-karena-perkosaansalah-alamat- yang-salah-bapaknya.html (diakses pada tanggal 9 Desember 2014 pukul 15:30 WIB)

http://m.kompasiana.com/post/read/668500/ 3/legalisasi-aborsi-karena-perkosaansalah-alamat- yang-salah-bapaknya.html (diakses pada tanggal 9 Desember 2014 pukul 15:30 WIB) 